\title{
Investigating the use of a Website as a Promotional Tool by Matjhabeng Non-Profit Organizations
}

\author{
Molefi Motsoenyane \\ (Lecturer, School of Information Technology, Central University of Technology, South Africa)
}

\begin{abstract}
The profit \& non-profit organizational long-term success of promotional campaigns and marketing communication are affected by the effective use if information technology (IT). Web presence allows organizations to put all sorts of media, visual, text, sound, video and animation to promote their services. The purpose of this study is to examine how Non-Profit Organizations (NPO's) utilise their websites as a public relations tool. To accomplish this, a research was conducted utilising questionnaires. From the analysis made, the researcher found that more organizations deemed their primary promotion tool to be telephones and cell phones and a large population of NPOs do not use email and internet because of a low level on internet literacy among them.
\end{abstract}

Keywords - Website, Website promotion, Non-Profit Organization, NPOs, Public Relations

\section{Introduction}

Companies spend as little as $2 \%$ and as much as $10-15 \%$ of revenue on IT, including the on-going cost of keeping the existing IT operational activities going well as new investment in development and enhancement projects [1]. Today people use the Internet to search information, buy and sell products, make travel arrangements, conduct banking and download music and videos, among other activities. Internet is also accessible through mobile phones and thus increasing speeds in communications and doing business transactions [2].

Having recognised the potential of the Internet, many organizations have incorporated it into their marketing communication strategies and are promoting their products and services through web pages. However the potential that the Internet provides for all organizations, many organizations have not harvested its benefits because of lack of knowledge or resources [3].

While businesses and governments are at the forefront of Internet adoption, non-profit organizations have been slow to integrate this ever-growing technology and are perceived to be up to five years lagging behind the for-profit sector. With the vast benefits that are provided by the internet, the focus has always been on the for-profit organization. The services provided by non-profit organizations makes the Internet more appealing to this kind of organization than the for-profit organization [4].

The non-profit organization are either not aware of the potential of the Internet to provide services like promoting their services or they are not technologically resourceful. With the fast growing Internet services, the cost of having a website has become very low. Some of the organizations are even giving free websites and free web design tools to organizations who register with them. The purpose of this study is to investigate the extent to which NPO's are adopting the Internet as a promotion tool. The researcher begins with a brief outline of Internet usage in NPOs and dwells deeply in website usage as a tool for public relations or promotion.

\section{Literature}

The digital world has changed communication within organizations and between organizations and their various communities. Several public relations researchers have concluded that public relations and the internet are inseparably linked, offering examples of how organizations use the internet to communicate with members of its community [5].

For many non-profit organizations, promotion is equated with the marketing and it is a key factor in successful marketing. Building links with their communities has become increasingly important for non-profits. Promotional tools used by charities are integral to their mission. Services to both clients and donors would fail without them. With so much competition for funding in recent years, donors need to know more about causes and how funds are administered. Communication strategies are therefore essential to deliver accountability. Clients need to be made aware of how to access support, and communicating with them has therefore become more significant [6].

The promotion element of marketing refers to how marketing communications are used to inform clients and other stakeholders about an organization and its products or services. It is a marketing function concerned with persuasively communicating to target audiences the components of the marketing program in order to facilitate exchange [7]. 
A thorough and well-designed website can constitute a very strong promotional tool for the non-profit. This is of paramount importance as people around the world are using the Internet at an increasing pace. A website is the heart of the online marketing program, the focus of all marketing communications, and the single most important means of communication for transportation [8].

A non-profit organization is defined as a body of individuals that associate for any of the three purposes: (1) to perform state-delegated public tasks; (2) to perform in-demand public tasks which neither the government nor the for-profit organizations are willing to fulfil or (3) to influence the policy direction in the government, the business sector or any other non-profit organization. More specifically, the mission of NPO's is built around services, which have a social value of "doing good for the community" [4].

\section{Non-Profit Organizations And The Internet}

Non-profit organizations frequently struggle to overcome problems associated with funding revenues, growing competition from other non-profit and for-profit organisations, increased demands for accountability, and accommodations to new technology. While non-profits today are acting much like for-profit businesses, they still are lagging in their use of professional public relations practices. However, the internet offers nonprofit organizations unique opportunity to reach multiple communities, including volunteers, donors and journalists [5].

People have used the Internet for diverse interests such as making major investment decisions, starting new hobbies and assisting themselves to deal with illness. Email continues to be the major application of choice, but websites are used for advertisements, dissemination of information, and solicitation of customers, direct sale of products and services, and education [9].

The benefits provided by the Internet to the business sector calls for an increase in its use in the NPO sector. For example, Internet-based networking provides an immense opportunity for enhancing the way in which non-profit organizations fulfil the needs of their community and the way they share their information with their stakeholders. The network of obtainable opportunities using the Internet enables NPOs not only to promote their social goals and gain wider visibility and public image, but also to disseminate their services and programs in attracting and diversifying funding sources [4].

Organizations that feel that there is a need to have an Internet presence to project a favourable corporate image and create a stronger brand identifies with their members are more inclined to adopt the Internet. However, these benefits can only be realised if the non-profit organization recognises that a critical mass of its member base are early adopters of the technology and use the Internet. The probability that a nonprofit organization has a web site will be significantly influenced by its mission; organizations with science and technology missions are more likely to have a website compared to others [9].

Through the Internet, NPOs can target a broad range of information about customers and may select the information that is of interest to them. The Internet has been widely acknowledged as an important tool for educating, exchanging ideas, raising awareness, promoting various causes (activism) and delivering services [4].

\section{Web Site As A Promotion Tool For Non-Profit Organizations}

Because consumers visit web sites with the objective of acquiring useful information or being entertained, it follows that web sites are of most value when they fulfil consumers' goal-seeking needs by providing useful information rather than attempting to dazzle with excessive graphic cleverness. The architect's advice that "form follows function" certainly applies to the web sites as an online promotion tool [10].

A website should be a supporting component of any marketing communication campaign. This could include creating options for visitors to give their contact information expressing their needs, complaints or the kind of help they can provide to the organization. This kind of information must be visible in from the homepage. Maximising the site's marketing effectiveness is important, as it will attract visitors' attention to the services provided by the organization [8].

Non-profit websites can be an important communication tool for reaching the public and the constituencies served, providing information that enables dissemination of missions, member and donation solicitation and creation of greater public understanding of activities. The global reach of Internet provides a powerful and cost effective way of soliciting interest in programs and in creating rallying points for coalescing membership in cyberspace [9].

Web sites often are among many resources in an arsenal of communication strategies for businesses and companies that include advertising, public relations, philanthropy, issues management and community relations. However, for smaller organizations, such as activists and non-profit organizations, websites play a critical role as a primary resource for communicating with, and responding to, stakeholder groups. The Internet provides a low-cost, direct, controllable communication channel that can extend NPO's efforts in outreach and promotion [5]. 
Promoting the website means promoting the non-profits itself. A successful marketing and promotion strategy should consider the following [8]:

- The website address must be used on all printed advertisements and letterheads.

- The website must include the links to other websites, and these sites must link back to the website.

- The website must be listed in free directories and search engines found on the web.

Given its interactive potential, the internet is the ideal medium for public relations practice because the audience's power is heightened for better two-way communication and relationship building. Using two-way communication between the organizations and publics is a major attribute of excellent public relations. Interactivity is defined as the degree to which a communication technology can create a mediated environment in which participants can communicate and participate in reciprocal message exchanges [5].

\section{Research Methodology}

This study has been carried out to identify the use of Internet by the non-profits and provide recommendations for a website effective and efficient development and use, which will lead to both the organization and the community it is serving [15]. It is the purpose of this study to investigate the use of website design as an effective promotional tool for Non-Profit Organizations in Matjhabeng municipality. Matjhabeng Local Municipality is an administrative area in the Lejweleputswa District of the Free State in South Africa that includes the following cities: Welkom, Virginia, Odendaalsrus, Hennenman, Ventersburg and Allanridge.

The objectives of this study are:

- To indicate the importance of NPO's to have a web presence

- To indicate the value of utilizing a web site for public relations purposes

- To investigate the level of website promotion by Matjhabeng NPOs

The research strategy that was used to put into action this empirical research is a quantitative study. In quantitative study, the researcher typically is concerned with quantities and measurements, attempting to make sense of, or interpret in terms of the meanings people bring to them' [11].

Information was obtained through an empirical study. The instrument used to gather information was questionnaires. Staff members working with the core functions of a non-profit organization like admin staff or chairpersons were given questionnaires and were given ample time to respond. Respondents were assured that information gathered will be treated confidentially and that the results will be used for research purposes only.

The structure of the interview will begin with close-ended questions on the demographics and introductory in nature. Then other close-ended questions will follow [12]:

$>$ their computer literacy level;

$>$ internet literacy level;

$>$ methods utilised for communication and promotions

\section{Sampling and Unit of analysis}

For this study, 214 NPOs in Matjhabeng Municipality were used as the research sample. This list of NPOs was derived from the registered NPOs from Department of Social Development - Free State. When the research was done, some of the non-profits in this list were no longer in operational because they were nonexistent in the address specified in the list. The researcher managed to get 101 responses for this research. Possible respondents were selected randomly to cover to cover as much representatives of the non-profit population. This was done for sole purpose of getting each population member an equal and independent chance of being selected as part of the sample [13].

The unit of analysis for this research were NPOs from the following sectors:

- Health

- Education

- Religion

- $\quad$ Social Services

\section{Analysis \& Results}

Table 1 illustrates a large portion of the NPOs that the researcher came in contact with are in the education sector. This is the reason why the education sector is dominating other sectors in terms of its total employees (708). Even though this is the case, the education sector is the least in terms of average percentage of staff who are computer literate (36\%). 
TABLE I

\begin{tabular}{|c|c|c|c|c|c|}
\hline & $\begin{array}{c}\text { Number } \\
\text { of } \\
\text { NPOs }\end{array}$ & STAFF & $\begin{array}{c}\text { Literate } \\
\text { MISSION }\end{array}$ & $\begin{array}{c}\text { Average } \\
\text { PC } \\
\text { Literate } \\
\text { Per sector }\end{array}$ & $\begin{array}{c}\text { PC } \\
\text { Literate } \\
\text { Overall }\end{array}$ \\
\hline Education & 66 & 708 & 271 & $36 \%$ & $46 \%$ \\
\hline Health & 14 & 466 & 203 & $59 \%$ & $35 \%$ \\
\hline Religion & 6 & 71 & 59 & $87 \%$ & $10 \%$ \\
\hline Social Services & 15 & 121 & 52 & $50 \%$ & $9 \%$ \\
\hline TOTAL & 101 & & 585 & & \\
\hline
\end{tabular}

As in Table 2 below, $3 / 4$ of NPOs utilise telephones as a primary means of communication with the health services on top of the list. The social services sector utilises the cell phone for their promotions more than they utilise their telephones.

TABLE 2

PRIMARY MEANS OF COMMUNICATION OR PROMOTION

\begin{tabular}{|c|c|c|c|c|c|c|}
\hline MISSION & $\begin{array}{l}\text { Cell } \\
\text { phone }\end{array}$ & Events & Fax & Letters & Pamphlets & Telephone \\
\hline Education & 35 & - & 2 & 12 & - & 52 \\
\hline $\begin{array}{l}\text { Health } \\
\text { Services }\end{array}$ & 10 & - & - & - & - & 90 \\
\hline Religion & 17 & - & - & - & - & 83 \\
\hline $\begin{array}{l}\text { Social } \\
\text { Services }\end{array}$ & 43 & 7 & - & 7 & 7 & 36 \\
\hline
\end{tabular}

When it comes to secondary means of communication or promotions, Table 3 below point out that web promotion is as low as $0 \%$ in health, religious and social services sector, and is as low as 3\% in the education sector. The use of email as a promotion tool is also less than $20 \%$ in all other sectors and with the health services as low as $0 \%$.

\begin{tabular}{|l|r|r|r|r|}
\hline \multicolumn{6}{|c|}{ TABLE 3 } \\
\hline SECONDARY MEANS OF COMMUNICATION OR PROMOTION \\
\hline MISSION & Education & Health & Religion & $\begin{array}{l}\text { Social } \\
\text { Services }\end{array}$ \\
\hline Cellphone & $27 \%$ & $55 \%$ & $17 \%$ & $13 \%$ \\
\hline Email & $7 \%$ & $0 \%$ & $17 \%$ & $14 \%$ \\
\hline Events & $0 \%$ & $0 \%$ & $0 \%$ & $13 \%$ \\
\hline Fax & $12 \%$ & $27 \%$ & $67 \%$ & $13 \%$ \\
\hline Internet & $3 \%$ & $0 \%$ & $0 \%$ & $0 \%$ \\
\hline Letters & $42 \%$ & $0 \%$ & $0 \%$ & $33 \%$ \\
\hline Posters & $2 \%$ & $0 \%$ & $0 \%$ & $0 \%$ \\
\hline Roadshows & $0 \%$ & $0 \%$ & $0 \%$ & $7 \%$ \\
\hline Telephone & $6 \%$ & $45 \%$ & $0 \%$ & $7 \%$ \\
\hline $\begin{array}{l}\text { Verbal } \\
\text { Communication }\end{array}$ & $2 \%$ & $0 \%$ & $0 \%$ & $0 \%$ \\
\hline
\end{tabular}

It is clear from Table 1 that the education sector is leading in terms to number of computer literate staff and that is why they also lead in terms of internet skills levels as shown in Figure 1 below. The education sector is leading in both skilled and those who need ICT training $(10 \%+22 \%)$. Even though the education is leading others, the percentage of both skilled and expert internet users is low in all sectors (below 15\%). 


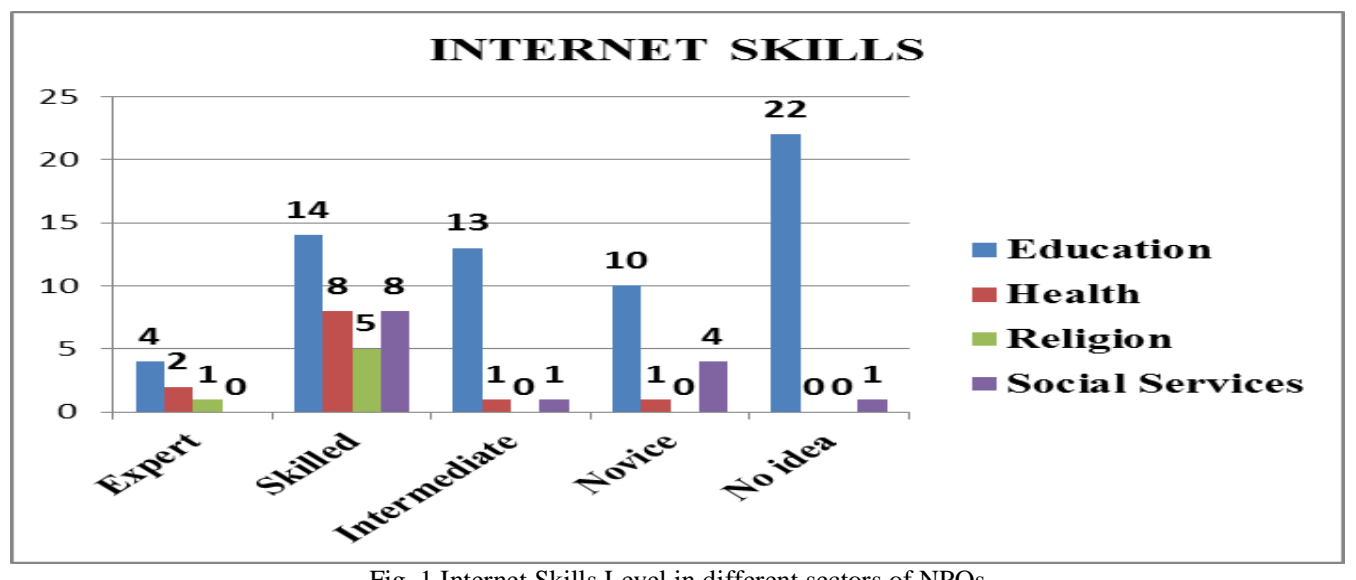

Fig. 1 Internet Skills Level in different sectors of NPOs

The knowledge of using email it is not an exception. Figure 2 below, indicates that a large portion of respondents' email skill level is below $20 \%$ in all sectors. This could be the reason why there is a low percentage in using email as a promotion tool. Because of the relative low cost of messages, email should be a practical and efficient way to maintain communications with an organization's constituencies.

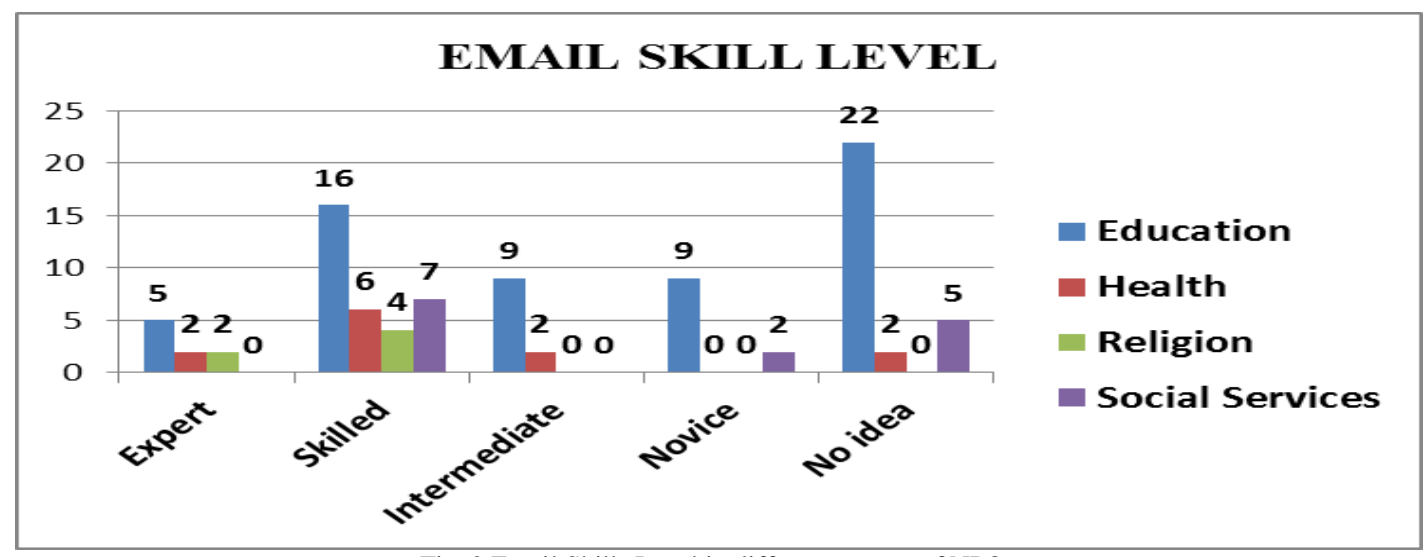

Fig. 2 Email Skills Level in different sectors of NPOs

In South Africa, Prodder is the most comprehensive online directory about NPOs and other development organizations in South Africa. Prodder website has about +3940 listed NPOs in its online directory. NPO Associated Networks SA has \pm 460 NPOs in its online directory while the Department of Social Development has a register of \pm 89119 NPOs. As indicated in Table 4 below, NPOs websites appearing under Prodder and NPO Associated Networks SA constitute about 5.05\% of the total NPO in the database of Department of Social Development.

TABLE 4

NPO NETWORKS IN SOUTH AFRICA

\begin{tabular}{|c|c|c|}
\hline ORGANIZATION & Number of NPOs & Source \\
\hline NPO Associated Networks SA & 460 & {$[14]$} \\
\hline Prodder & 3940 & {$[15]$} \\
\hline Department of Social Development & 87119 & {$[16]$} \\
\hline
\end{tabular}

This low percentage in Internet presence is significant demonstration of low web promotion by NPOs and this could be linked to high percentage of staff lacking internet and email skills especially in the education sector. This difference in percentages between these sectors raises a question about the advisability of generalizations about the non-profit sector as a whole, and it suggests the value of mission-specific studies in determining pervasiveness of Internet use. Since each sector will have its mission and vision and strategies different from any other, their need for a particular publicity media will also differ. 


\section{Limitations And Future Research}

The sample size chosen limit the ability of this research to generalise its findings to apply in all areas. NPOs are different in their objectives and therefore their need for the Internet will differ depending on their objectives. The research is restricted to information on the articles mentioned and the stats derived from Matjhabeng Municipality and the websites mentioned. Information from articles came from a small sample from leading non-profit organizations in the United States while the stats from South Africa did not take into consideration NPOs that did not register with either Prodder or NPO Associated Networks SA.

Future studies should study the non-profit organization in depth in South Africa and the impact their websites are making in their communities and to the organization. Further studies should be conducted in different countries according to different types of NPO sectors because different cultural, societal and economic factors might affect the development and usage of websites. Focus should also be on how different sectors of NPO's can employ this powerful tool of Internet. It is hoped by the researcher that this study serves as a stepping-stone for further studies in this area.

\section{Conclusion}

The use of a website as a promotional tool for Non-Profit Organizations can attract people from all around the world to use their services with just a mouse click. They provide convenience and save time for people by allowing them to go online to get the information they need. In this way, the community knows the benefits because they get the information faster.

From the analysis made, it is clear that non-profit organizations do need skills training in internet literacy before web presence is recommended. The study gave a glimpse of the use of websites by NPOs for promotional purposes at a very low percentage. Therefore, NPOs need to engage in excellent public relations efforts in their websites in order to make their message and services get to the masses. Even though is the case, the challenge remains to serve those constituencies who may not be up-to-date technologically. It is impossible to recommend web presence to an organization whose members have no clue what the Internet is or simple how to use it. Hence, further research must be done in this field as not that much attention is on it.

\section{References}

[1] R. Benson, T. L. Bugnitz, and W. B. Walton, From Business Strategy to IT Action. Right Decisions for better bottom line (New Jersey: John Wiley \& Sons, Inc, 2004)

[2] R. Stair, G. Reynolds, and T. Cheney, Principles of Business Information Systems. (London: Cengage Learning EMEA, 2008)

[3] J. Napoli, M. T. Ewing, and L. F. Pitt, Factors affecting the adoption of the Internet in the public sector, Journal of Non-profit \& Public Sector Marketing, Vol. 7 (4), 2000, 77-88

[4] J. C. Pinho, and I. M. Macedo, The Benefits and Barriers Associated with the use of the internet within the Non-Profit Sector, Journal of Nonprofit \& Public Sector Marketing, Vol. 16 (1/2), 2006, 171-184.

[5] H. M. Yeon, Y. Choi, and S. Kiousis, Interactive Communication Features on Nonprofit Organizations' Webpages for the Practice of Excellence in Public Relations. Journal of Website Promotion, 2005, 61-81.

[6] M. Kinnel, and J. MacDaugall, Marketing in the Not-for-Profit Sector (Oxford: Butterworth-Heinemann, 1997)

[7] D. Chaffey, F. Ellis-Chadwick, K. Johnston, and R. Mayer, Internet Marketing Strategy, Implementation and Practice (Essex: Pearson Education Limited, 2006).

[8] D. Vrontis, D. Ktoridou, and Y. Melanthiou, Website design and development as an effective and efficient promotional tool: a Case study in the Hotel Industry in Cyprus. Journal of Website Promotion, Vol. 2, 2004, (3/4).

[9] H. P. Tuckman, P. Chatterjee, and D.Muha, Nonprofits Websites: Prevalence, Usage and Commercial Activity. Journal of Nonprofit \& Public Sector Marketing, Vol. 12, 2004, (1).

[10] T. Shimp, Integrated Marketing Communication in Advertising and Promotion. (South-Western: Cengage Learning, 2010).

[11] J. Biggam, Succeeding with your Master's Dissertation - a ste-by-step handbook. 2nd Ed (Berkshire: Open University Press, 2011).

[12] B. Blumberg, D. Cooper, and P. Schindler, Business Research Methods. 2nd Edition (New York: McGraw-Hall Education, 2008).

[13] N. J. Salkind, Exploring Research. 7th Edition. (New Jersey: Pearson Prentice Hall, 2009).

[14] D. Ndlela, SA Website for Non Profit Organisations. Retrieved September 14, 2012, from Non Profit Organisations NPO Guide SOUTH AFRICA: http://www.npo.org.za/npoListing/00index.htm

[15] SANGONET, South Africa's most comprehensive directory of NGOs and development organisations. Retrieved September 14, 2012, from Prodder Directory: http://www.prodder.org.za

[16] R. Ramabale, ALL ABOUT NONPROFIT ORGANISATIONS. Retrieved September 14, 2012, from Department of Social Development - Non Profit Organisations: http://www.ngo.gov.za/frmSrchM.aspx 